\title{
Supervision of local government to village regulation in regional autonomy are reviewed theory
}

\author{
Putra Astomo \\ West Sulawesi University Social and Politic Science Faculty Department Law \\ Email : puteraastomo_hukum@yahoo.co.id
}

Article history:

Received, July 15, 2017

Revised, September 30, 2017

Accepted, November 212017

Keywords:

Local Government

Supervision,

Village Regulation

The Law Number 6 of 2014 years and PP Number 43 of 2014 years are law product which to rule supervision of local government to village regulation in regional autonomy are reviewed. PP Number 43 of 2014 years reads that the technical guidelines on the rules in the village are set by regulation, so which mandates the need for regulation as a regulatory technical guidelines in the village, it also formed Minister Regulation Number 111 of 2014 years about Technical Guidelines Rules In the Village. The method that is used the approach of law (statute approach). This method is done by examining all the legislation and regulations relevant to the legal issues being addressed. The result of this research are supervision is done in two forms, including evaluation and clarification. It was concluded supervision of local government to village regulation in regional autonomy are reviewed as stipulated in Minister Regulation Number 111 of 2014 years are done in two forms, including evaluation and clarification.

Copyright $\odot 2017$ Indonesia Prime. All rights reserved

\section{Introduction}

In 2014 years, the village changed settings are marked with the enactment of Law Number 6 of 2014 years about village of replacing Law Number 32 of 2004 years about Regional Governments. Similarly, PP Number 72 of 2005 years is also no longer valid because the birth PP Number 43 of 2014 years about The Implementation Regulation of Law Number 6 of 2014 years about Village.

The village has the powers as stipulated in Article 19 which says that the authority of the village includes: authority based on the origin of the rights, the village scale local authority, authority commissioned by the Government, Provincial Government, or the Government of Regency/City, and other powers assigned by the Government, Provincial Government, or the Government of Regency/City in accordance with the provisions of the legislation.
This study will focus on the supervision of Local Government to the Village Regulation was necessary reestablished him about the intricacies of Village Regulations. Definition of Village Regulations mentioned in Article 1 paragraph (7) which states that Village Regulations are regulations set by the village chief after being discussed and agreed on Village Consultative Body.

Moreover, the existence of village regulation is intended to regulate in detail the various authorities owned by the village. It is mentioned in the General Elucidation of Law Number 6 of 2014 years that the Stipulation of Village Regulations are descriptions of the various competencies of the village refers to the provisions of legislation is higher.

Village regulations as legislation would exist exclusively at the village level as mentioned in Article 69 Paragraph (1), which reads that type regulation in the village consists of Village 
Regulations, together with the village chief rules, and regulations of the chief. As one type of regulation in the village, then the village regulation always get the supervision of the Regional Government, either while still in the draft and after becoming a village regulation. Supervision was conducted in order to keep the existence, status, and enforceability of Village Regulations is not contrary to the public interest and / or legislation in force.

Monitoring carried out by the Local Government of the village regulations stipulated in Law Number 6 of 2014 years with PP Number 43 of 2014 years include: Article 112 Paragraph (1) of Law Number 6 of 2014 years read that the Government, Provincial Government, and the Government of Regency/City Government and supervise the village, Article 115 Paragraph (1) letter e of Law Number 6 of 2014 years read that the guidance and supervision of the Government of the Regency/City as meant in Article 112 Paragraph (1) is the evaluation and supervision of Village Regulation, Explanation of Article 115 Paragraph (1) letter e of Law Number 6 of 2014 years read that the term "supervision" is included cancellation of Village Regulations, Article 84 Paragraph (4) PP Number 43 of 2014 years reads that the village has enacted regulations submitted to the regent/mayor as a guidance and supervision of at least 7 (seven) days after its promulgation, Article 87 PP Number 43 of 2014 years that the Village Rules and regulations village head that contrary to public interest and/or the provisions of the legislation which is higher canceled by the regent/mayor, and Article 89 PP Number 43 of 2014 years reads that the technical guidelines on the rules in the village are set by regulation.

Therefore, problems as described earlier, then the problem can be defined is how to shape the supervision of local government to the village regulations are reviewed by Law Number 6 of 2014 years about Village in Indonesian?

\section{A. Review of Literature}

\section{The Concept of the Village}

According to Van Vollenhoven, that the village is the unity of indigenous peoples. Study of the legal community to focus on the public focused on the community, the community that has characteristics of unity and harmony and is bound by the same cultural value system, to know each other, have a relatively intimate relationship, and the spirit of mutual help. Community customary law derived from the existence of the communal society. Customary law community because the community on the community to develop institutions that used to meet their needs both physically and mentally. In a further development the institutions that formed the foundation for the implementation of the social system. With the social system established by the institutions of self-developed and maintained as the basis of the life system is formed of indigenous peoples.

According to Ter Haar, that the village is a unity of indigenous peoples. Furthermore, he argued that indigenous people is the unity of humanity as a whole, to settle in certain areas, have rulers, has a wealth of tangible or intangible, in which members of their respective units to experience life in society, is a nature and none of the members has a mind or a tendency to want to dissolve the bond that has grown it or leave in the sense of escape from the bonds it forever.

\section{Theory of Legislation}

The term legislation (legislation, wetgeving, or gesetzgebung) in some literature has two different senses.

According to Fockema Andreae, that legislation, wetgeving or gesetzgebung could mean (1) the process of formation of state regulations, both at the central level and at the regional level, (2) legislation as the result of the establishment of regulations, both at the central level and at the regional level.

\section{The Concept of Norm}

Norm is derived from the word nomos, which means value and then narrowed its means to be a legal norm. While the rules in Arabic, qo'idah means the size or gauge value. Norms or rules are institutionalizing the values of good and evil in the form of rules that contain permissibility, suggestions, or command. Both suggestions and commands can contain rules that are positive or negative recommendation to include norms for work or advice to not do 
something, and norms commands to perform or an order not to do something.

According to Maria Farida Indrati, that the norm is a measure that must be complied with by a person in conjunction with each other or with their surroundings. The term norm, which comes from the Latin, or rules in Arabic, and is often referred to guidelines, standards, or rules in Indonesian, initially defined by the right-angled, which is perpendicular which to measure or benchmark to form a desired angle or line. In its development, the norm was interpreted as a measure or standard for a person to act or behave in society. Thus, the core of a norm is all the rules that must be obeyed.

\section{The Concept of Hierarchy Norm}

Regarding the forms (juridisch voermen), essentially according to Hans Kelsen, that norm was tiered and layered in the composition of the hierarchy, so that the norm under sourced and based on the norms higher. Norma higher sourced and based on the norms of higher again. And so on until it stops at the highest norm called basic norm (Grundnorm, basicnorm, fundamentalnorm). Therefore, in the system of legal norms including norms dynamic (nomody namics) because the law was always formed and removed by the agency or the competent authority to shape. The law is valid if made by the institution or the competent authority based on the shape and thus higher norm (inferior) can be formed by the norm of the higher (superior), and the law was tiered and layered to form a hierarchy.

One theory of Hans Kelsen received much attention is the hierarchy of legal norms and chains that form a pyramid legal validity (stufentheorie). One of the figures who developed the theory was a pupil of Hans Kelsen, namely Hans Nawiasky. The composition according to the norms of the theories are norm fundamental state (Staatsfundamentalnorm), the basic rule of the country (Staatsgrundgesetz), law formal (Formellgesetz), and implementing rules and regulations of the autonomous (verordnung en autonome satzung).

Staatsfundamentalnorm is a norm which is the basis for the formation of the constitution or Basic Law (Staatsverfassung) of a country. The legal position of a Staatsfundamentalnorm is as a condition for the entry into force of a constitution. Staatsfundamentalnorm is before the constitution of a country. According to Hans Nawiasky, the highest norms by Hans Kelsen referred to as the basic norm (basicnorm) within a country should not be referred to as staatsgrundnorm but Staatsfundamentalnorm or fundamental norm of the state. Grundnorm basically did not change, while the supreme norms change, for example by means of a coup or revolution.

\section{The Concept of Norm Supervision Law}

In the terminology, the term surveillance is also called controlling, evaluating, appraising, correcting or control.

In practice, known that there are three kinds of legal norms that can be tested or commonly referred to as a norm control mechanism. All three are equally a form of legal norms as a result of the decision making process of law, namely: (i) normative decision which contains and is the setting (Regeling), (ii) normative decision which contains and is the determination of administrative (beschikking), and (iii ) that contains a normative decision and judgment are (judgment) commonly called the verdict. All three forms of legal norms, there is an individual and concrete norm, and there is also a general and abstract norm. The verdict and beschikking always individual and concrete norm, while Regeling always be general and abstract norm. Against various forms of legal norms can be done through the control or supervision of what is commonly referred to as a control mechanism of legal norms (legal norm control mechanism). Control of the legal norms that can be done through the supervision or control of political, administrative controls, or through control law (judicial).

According to Bagir Manan, that in order to keep the rules of the constitution contained in the Constitution and the laws are not violated other constitutional or criss (either in the form of legislation or in the form of the actions of other governments), there needs to watch her weight and ordinances. In the literature there are three broad categories of testing legislation and acts administrative state, namely: (1) Testing by the judiciary (judicial review), (2) Testing by bodies 
that are political (political review), and (3) testing by the official or state administrative bodies (administrative review).

\section{B. Discussion}

Article 89 of Regulation Number 43 of 2014 years, which mandates the need for regulation as a regulatory technical guidelines in the village, it also formed Minister Regulation Number 111 of 2014 years on Technical Guidelines Rules In the village.

The Minister Regulation Number 111 of 2014 years become to the next regulation about supervision of local government to village regulation. That form of supervision of local government to village regulation is done in two forms, namely: 1. Evaluation is organized into several chapters covering: Article 14 reads as follows: 1) The draft Regulation of the Village of APB Village, levies, layout, and organization of village government that has been discussed and agreed upon by the Village Head and BPD, delivered by the head of the village to the Regent / Mayor Through the district or other designations later than three (3) days since it was agreed to be evaluated, 2) In the case of the regent / mayor does not provide evaluation results within the time limit, the Village Regulations apply by itself. Article 15 reads as follows: 1) The results of the evaluation of the draft Regulation of the village as referred to in Article 14 paragraph (1) shall be submitted by the Regent / Mayor maximum of 20 (twenty) working days after the receipt of the draft regulation by the Regent / Mayor, 2) In the case of Regent / Mayor has given the results of the evaluation referred to in paragraph (2), shall fix the Village Head. Article 16 reads as follows: 1 ) The Village Chief improve the design of village regulations referred to in Article 15 paragraph (2) not later than 20 (twenty) days of receipt of the evaluation results, 2) The village chief may invite BPD to improve the design of village regulations referred to in paragraph (1), 3) The results of the followdelivered corrections and Village Heads to the Regent/Mayor through District. Article 17 reads that in case the village chief does not follow results of the evaluation referred to in Article 16, paragraph (1), and remains set into a village regulation, Regent/Mayor cancels Village Regulations by the Decree of the Regent / Mayor.

Besides evaluation, the other foms is clarification. Clarification is organized into several chapters covering: Article 19 reads as follows: 1) Regulation village that has been enacted as referred to in Article 12 paragraph (1) shall be submitted by the village chief to the Regent/Mayor no later than 7 (seven) days since its enactment to be clarified, 2) The Regent / Mayor of clarifying the Village Regulations by forming a team of clarification later than 30 (thirty) days of its receipt. Article 20 reads as follows: 1) Results of clarification as referred to in Article 19 paragraph (1) can be: a. Clarification that are in accordance with the general interest, and/or the provisions of legislation which is higher; and b. clarification contrary to the public interest and / or the provisions of legislation higher, 2) In case of the clarification referred to in paragraph (1) of the Village is not contrary to the public interest, and / or the provisions of the legislation which is higher Regent/Mayor issued a clarification that contains the results of clarification that has been appropriate, 3 ) In case of the clarification referred to in paragraph (1) contrary to the public interest, and/or the provisions of the legislation which is higher Regent/Mayor cancels the Village Regulations by the Decree of the Regent/Mayor.

\section{E. Conclusion}

Based on the description that has been presented, then can concluded was supervision of local government to village regulation as stipulated in Minister Regulation No. 111 of 2014 years is done in two forms, including evaluation and clarification.

\section{References}

[1]Bushar Muhammad, 1986, Asas-asas Hukum Adat Suatu Pengantar, Jakarta: Pradnya Paramita.

[2]Hanif Nurcholis, 2011, Pertumbuhan dan Penyelenggaraan Pemerintahan Desa, Jakarta: Penerbit Erlangga. 
[3] Hans Kelsen, 1961, General Theory of Law and State, New York: Russel\&Russel A Divison of Atheneum Publisher Inc.

[4]Hans Nawiasky, 1948, Allgemeine Rechtslehre als System der rechtlichen Grundbegriffe, Cetakan Kedua, Einsiedeln/Zurich/Koln, Benziger.

[5] Jimly Asshiddiqie, 2006, Perihal UndangUndang, Jakarta: Konstitusi Press.

[6] Jimly Asshiddiqie dan Muhammad Ali Syafa'at, 2012, Teori Hans Kelsen Tentang Hukum, Cetakan Ketiga, Jakarta: Penerbit Konstitusi Press.

[7] Maria Farida Indrati S, 2007, Ilmu Perundang-Undangan 1;Jenis,Fungsi,dan Materi Muatan, Cetakan Kesembilan, Yogyakarta: Kanisus.

[8] Muh. Fauzan, 2006, Hukum Pemerintahan Daerah Kajian Tentang Hubungan Keuangan Antara Pusat dan Daerah, Yogyakarta: UII Press.

[9] Ni'matul Huda, 2005, Negara Hukum, Demokrasi Dan Judicial Review, Yogyakarta: UII Press. 